\title{
The weak data on the water-energy nexus in Spain
}

\author{
Diego Sesma-Martín ${ }^{\mathrm{a}, \mathrm{b}, *}$ and M. d. Mar Rubio-Varas \\ ${ }^{a}$ Economics Department, Public University of Navarre, 31006 Pamplona, Spain \\ ${ }^{b}$ Institute for Advanced Research in Business and Economics (INARBE), Spain \\ *Corresponding author. E-mail: diego.sesma@unavarra.es
}

\begin{abstract}
This paper focuses on the fact that the water-energy nexus remains an irrelevant issue on the energy policy agenda and on the priorities of the energy leaders in Spain. This is a striking fact given that this takes place in the most arid country in Europe, where almost two-thirds of electricity generation would have to be halted in the absence of an adequate water supply. We contend that part of the explanation may lie in the lack of official statistics and inconsistent sources of information on the water-energy nexus in Spain. To illustrate this point, we provide examples of the uneven data available for one of the most intensive freshwater users in the thermoelectric sector in Spain: nuclear power plants. Our research demonstrates the need for improved indicators as policy instruments in the water-energy nexus in Spain since it is impossible to improve what cannot be measured.

Keywords: Cooling technologies; Indicators; Policy evaluation; Policy instruments; Spain; Water-energy nexus
\end{abstract}

\section{Introduction}

The crucial role of water for human life is a scientific fact well recognized by society. Yet most people would not consider water as a basic input in our energy system. If asked about the issue, the average person would surely identify the link of energy and water by just evoking power dams. However, according to IEA (2013) and Delgado et al. (2015), nearly $80 \%$ of the world's electricity is generated in thermoelectric power plants which require water in their operation. Adding the $15 \%$ corresponding to hydroelectricity generation, the vast majority of today's global electricity generation would cease in the absence of water (that is, all hydroelectric production plus all thermal generation regardless of technology). In fact, the production of electrical power is one of the largest uses of water worldwide and, consequently, the mutual vulnerability of water and energy is considered as one of the most important concerns of the future (IEA, 2012b). Vast amounts of water are needed in power generation, mainly for cooling processes. In turn, there exists a vast international body of literature and technical reports doi: 10.2166/wp.2019.081

() IWA Publishing 2019 
describing the water requirements for power generation by technology. Some examples are Kenny et al. (2009), Macknick et al. (2012), and Meldrum et al. (2013).

In this context, some international institutions have developed proposals to address the challenges of energy resources planning and water (for example, the Thirsty Energy Initiative from the World Bank) ${ }^{1}$ and many authors have researched this matter from different perspectives (IEA, 2012a, 2012b; WWAP, 2014; Delgado et al., 2015). Water shortages have already impacted the energy sector in many countries albeit in different ways. For example, whereas in India, several thermal power plants have shut down due to water scarcity, in the USA or France, power stations have reduced their energy production as a result of high water temperatures preventing the proper functioning of cooling systems (Rodriguez et al., 2013). In line with this, the French case is especially relevant since the country currently gets about $75 \%$ of the total electricity from nuclear power plants and most of its reactors are cooled by water from rivers (World Nuclear Association, 2018). Moreover, several trends point to rising demands on energy and water due to the rapid population growth and expansion of economies due to globalization. Therefore, ensuring the future provision of water and energy is essential to guarantee the social and economic development of many countries.

According to the State Meteorological Agency (AEMET, for its Spanish acronym), in Spain the hydrological year ended in 2017 with a shortfall of $15 \%$ when compared to the historical average (1981-2010) and, hence, freshwater reservoirs of the country in 2017 were at their lowest state this century, representing the fifth driest year since 1990 (http://www.aemet.es/). While there is a long list of studies that have calculated the water footprint in agriculture, industry or even the tourism sector in Spain (De Stefano \& Llamas, 2012; Cazcarro et al., 2014; Duarte et al., 2014), the few studies on the water issue in relation to energy within the electricity sector have mostly referred to hydroelectric power plants and have ignored thermoelectric uses unlike the international literature. Some rare exceptions to this oversight are Carrillo \& Frei (2009), Hardy et al. (2012) and Sesma-Martín \& Rubio-Varas (2017).

The world at large has begun to think of the water-energy nexus as one of the priority issues at the global level. However, the energy-water nexus seems to remain irrelevant on the Spanish energy policy agenda. According to the data reported in the World Energy Issues Monitor (WEC, 2014, 2015, 2016, 2017), which ranks the most important issues according to the world's energy leaders, the water-energy nexus is not considered to be a matter of priority action in Spain. At a global scale, Spain ranks in a less prominent position than the other regions (e.g., OECD, North America, Asia, Africa, Latin America) and even behind the European average ${ }^{2}$. More specifically, this can be seen in Figures 1 and 2 that show some of the latest Energy Issues Monitor for Spain where the water-energy nexus is found at the bottom left margin of the graph, a position corresponding to issues perceived to be of lesser importance or those that are still not fully understood and require further investigation. Furthermore, comparing the size of the bubble corresponding to the water-energy nexus between the years 2014 (Figure 1) and 2017 (Figure 2), it can be seen how the water-energy nexus has lost relevance over the years (the larger the bubble, the greater the level of urgency). It was, in fact, regarded in 2017 as the issue with the least potential impact on energy in Spain (Figure 2). This contrasts with the social

\footnotetext{
${ }^{1}$ For more information, see: http://www.worldbank.org/en/topic/sustainabledevelopment/brief/water-energy-nexus.

2 This statement can be demonstrated by comparing Figure 8-The Energy-Water Nexus on p. 23 and the figure corresponding to Spain on p. 117 from WEC (2016).
} 


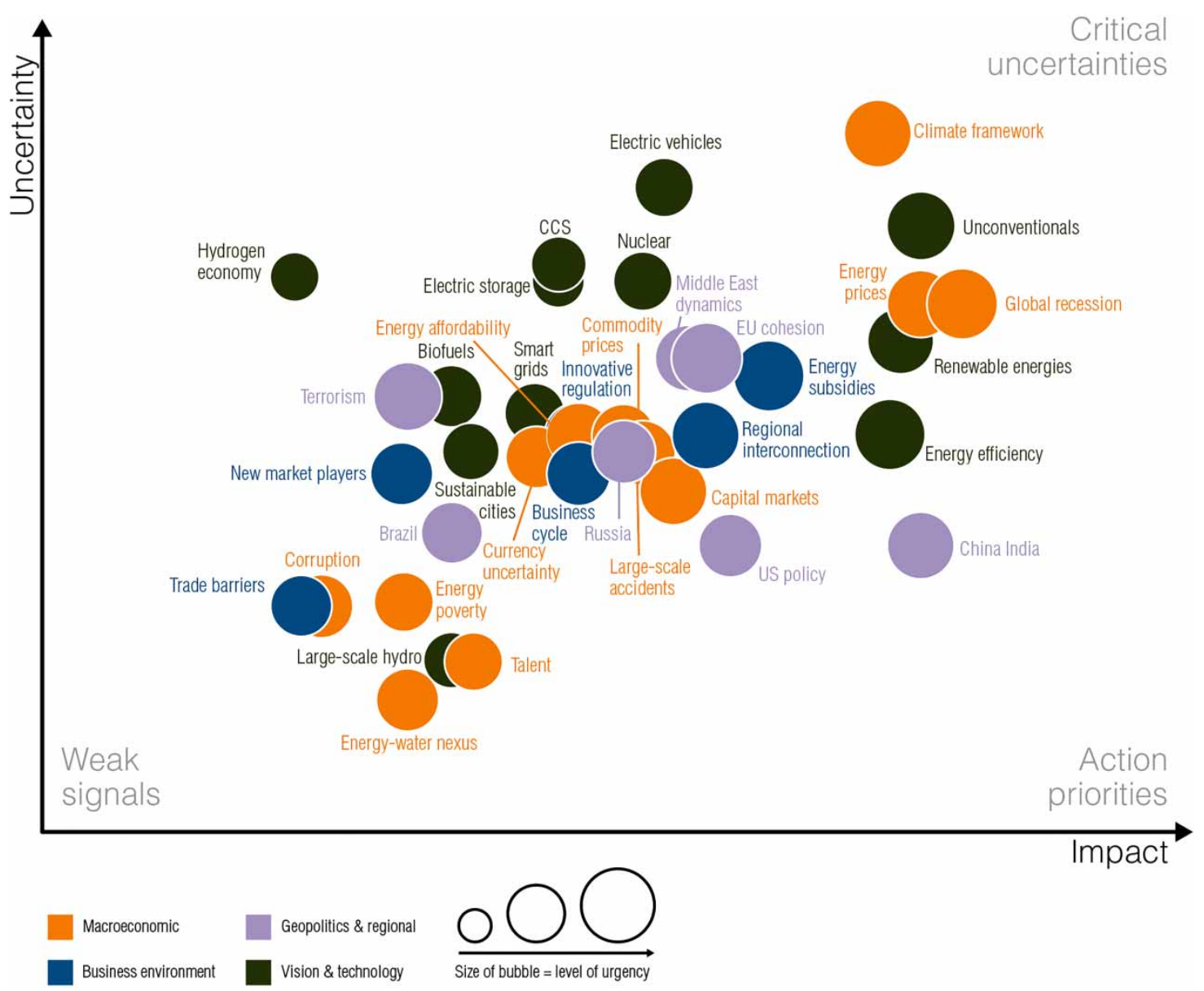

Fig. 1. WEC's 2014 World Energy Issues Monitor, Spain. Source: WEC (2014) (used by permission of the World Energy Council, London, www.worldenergy.org).

concern about water in Spain illustrated by the fact that the United Nations World Water Day is one of the three days that attracts most attention among the Spanish population (UN Water, 2016).

Our hypothesis is that two issues lie behind the fact that the water-energy nexus is not considered a primary issue in the Spanish policy agenda. First, the absence of appropriate data (in other words, factual information such as measurements or statistics) to understand the water-energy nexus, as we will show, is evident from the inconsistencies in the available sources of information published for analyzing the water needs of the energy sector in Spain. Second, the deficient understanding of the basic concepts with respect to water use (water withdrawal vs. water consumption) on the available sources which, in turn, omit information about the particular procedures or methodologies utilized to calculate such figures. These two sets of discrepancies (namely, in the available data and the unfitting use of inappropriate definitions) can result in incorrect interpretations that prevent a good estimate of the thermoelectric water footprint. At the same time, this can weaken the development of good management practices and the establishment of an efficient policy around the water-energy nexus. What is evident 


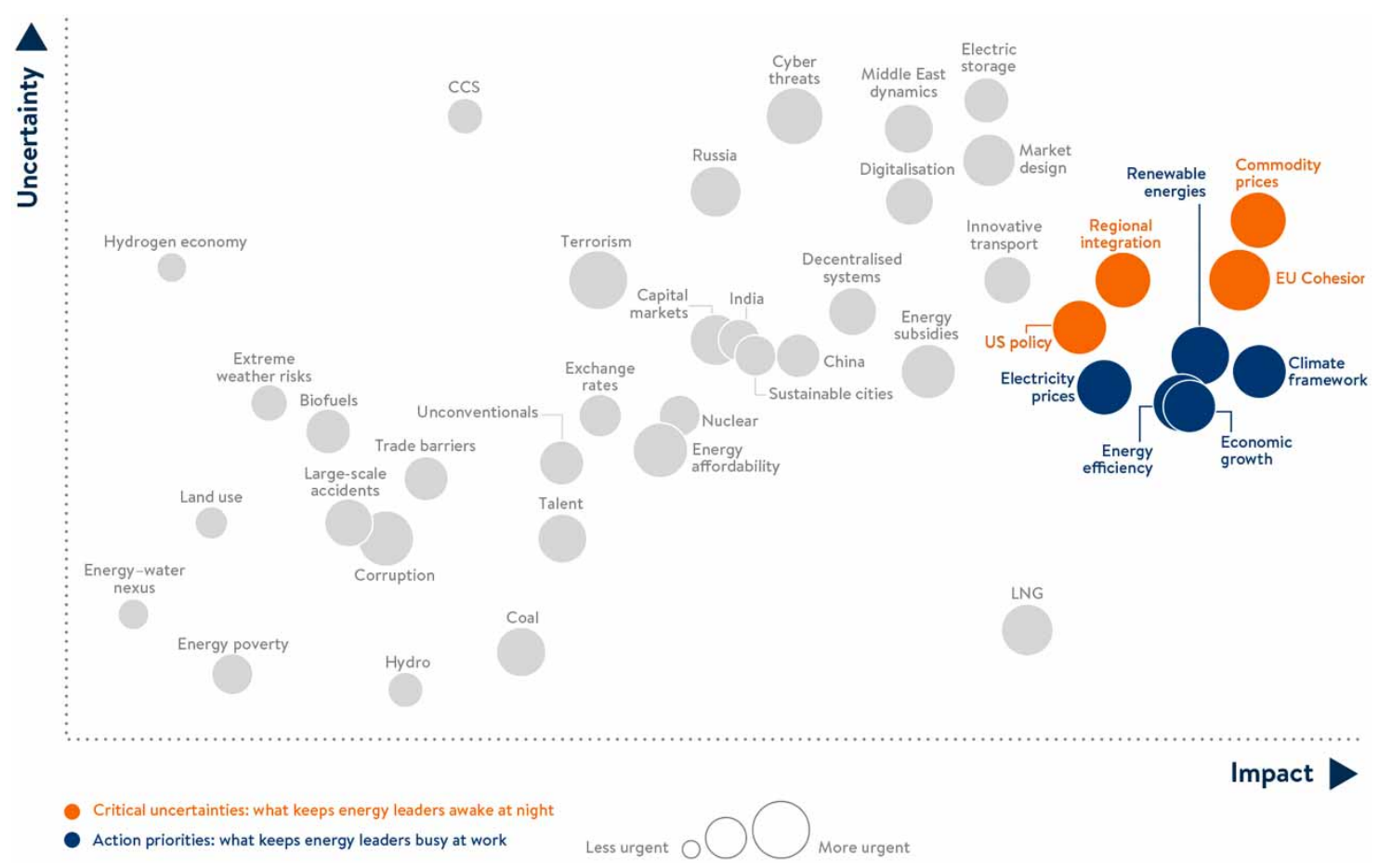

Fig. 2. WEC's 2017 World Energy Issues Monitor, Spain. Source: WEC (2017) (used by permission of the World Energy Council, London. www.worldenergy.org).

from the figures above is that there exists a lack of awareness among the stakeholders and Spanish society about the importance of water within the power sector.

Typically, the regulation of the electricity market acts on four components: generation, transmission, distribution, and commercialization. In Spain, from 1944 until the 1980s, a cartel of mostly privately owned companies, under the name of UNESA, self-regulated all aspects of the electricity market. The desire for change of the first Socialist government (elected in 1982) came to fruition with the nationalization of the High Voltage Grid, which was then again privatized in the late 1990s. 'What is certain is that the new model of regulation established in Spain brought about a first phase of vertical disintegration in the old regional private monopolies and created the means to achieve an optimization of the Spanish electricity system' (Garrues \& López-García, 2009). But it is relevant that the Spanish electricity production was organized as a private self-regulated business for most of the 20th century. Maybe as a consequence of this institutional setting, another aspect that emerges from the Spanish context is that thermal power stations in Spain do not pay for the water they use. Spanish legislation only included a fee for the amount of water used by hydropower plants from $2013^{3}$ but does not impose any fee for

\footnotetext{
${ }^{3}$ This fee was created by Law 15/2012, of 27 December, on fiscal measures for energy sustainability. However, Royal Decree 198/2015, of 23 March, which implements article 112 bis of the consolidated text of the Water Act and regulates the charge for the use of inland waters for the production of electricity in inter-community districts, specifies the aspects necessary for levying the charge and obliges hydroelectric plant owners to make the payment with effect from 1 January 2013, the date on which Law 15/2012 took effect.
} 
thermal power plants despite the large water volumes they require ${ }^{4}$. This legislative gap represents an additional argument to think about how the lack of political interest on the matter could be behind the lack of consistent evidence on the water-energy nexus.

These shortcomings put the correct management of water resources in Spain at risk. This seems particularly worrisome when it is the most arid country in Europe, where almost two-thirds of electricity generation would have to be halted in the absence of an adequate water supply (in 2017, 56\% thermoelectric plus close to $10 \%$ hydroelectric) (REE, 2017). Therefore, our aim in this communication is to expose these inconsistencies in the sources of information available in Spain when accounting for the thermoelectric water footprint. In this context, the thermoelectric water footprint refers to the volume of fresh water used for electricity generation in thermal power plants. We expose these issues by comparing and contrasting the available published sources of data of water use for the nuclear sector in Spain, the most water intensive of all thermal technologies, as collected by Sesma-Martín \& Rubio-Varas (2017).

\section{Methods}

There exist two key concepts when estimating the water requirements of a thermoelectric power plant: water withdrawals and water consumption. Water withdrawals are the total volume of water removed from a source by a power plant and water consumption is the amount lost to evaporation during the cooling process (Kenny et al., 2009; Sesma-Martín \& Rubio-Varas, 2017). In other words, water consumption is the volume of water withdrawn that is not returned to the source. In this way, differentiating between withdrawals and consumption is fundamental because even if large portions of the water return to the rivers, yet the opportunity cost exists for such water volumes. Likewise, water consumption and withdrawals have different associated environmental adversities (e.g., warmer water discharges, death of fish caught in the catchment systems) where appropriate public measures are needed to mitigate them; although in this paper, we only focus on the quantitative aspects.

In general, for elaborating a proper estimation of the water footprint for the thermoelectricity sector, first, power plants should be classified by type of fuel (coal, fuel-oil, gas, and uranium) and cooling technology (the most common systems are cooling towers and once-through systems). Each fuel and cooling system involves different water requirements and, consequently, produces different water withdrawals and consumption factors (e.g., open-loop systems withdraw much more water than cooling towers, but cooling towers evaporate much more water than open-loop systems) and, in turn, each region has specific geographical features that can condition water availability. Therefore, understanding the advantages and disadvantages of each cooling technology is essential for the correct management of freshwater resources.

For the sake of this communication, we concentrated on the water requirements of the nuclear power facilities, but our claims regarding the inconsistencies of water use data in the electricity sector in Spain apply to the whole thermoelectricity sector (Sesma-Martín, 2017). Nuclear water requirements tend to be larger per MWh (megawatt hour) generated than alternative thermal technologies (IEA, 2012a,

\footnotetext{
${ }^{4}$ There is an exception at regional level in Catalonia. Since 2004, the Catalan Government, through the Catalan Water Agency, imposes a tax (namely, Canon del agua) on freshwater resources used to refrigerate all those thermal and nuclear power stations of the region. This Canon del Agua is regulated by Legislative Decree 3/2003, of 4 November. The complete resolution can be found at https://www.boe.es/buscar/pdf/2003/DOGC-f-2003-90016-consolidado.pdf.
} 
2012b). We initiated this study on the basis of the data collected from a variety of sources in SesmaMartín \& Rubio-Varas (2017), which included Spanish nuclear facilities operating with fresh water that has been withdrawn from rivers or lakes. Plants working with sea water or refrigerating with gas were omitted. Therefore, the investigated nuclear power plants were Trillo I, Cofrentes, Almaraz I and II, Ascó I and II, Santa María de Garoña, and José Cabrera (known as Zorita). In their study, the authors excluded the Vandellós units I and II which use gas and sea water for cooling, respectively. For the plants considered, the authors did extensive research in public and private institutions to decipher the technical factors in order to estimate the water required to produce atomic energy in Spain (see Supplementary material from Sesma-Martín \& Rubio-Varas (2017)).

The information sources consulted included data from the Spanish Nuclear Safety Council (CSN for its Spanish acronym) and from the Libro Blanco del Agua, which represents the main references on water problems in Spain. Moreover, the data appearing on the websites of the River Basin Confederations (the main basin agencies in Spain) to which the different nuclear power plants correspond as well as water data published at the Spanish Official Bulletin (BOE) and the theoretical maximum water concessions of each power plant were reviewed. Greenpeace and the nuclear power plants themselves also collect some data in their environmental reports. Finally, the TRACER Project, a technical study on pollutants in rivers, also provided some timely data on the possible withdrawals of water from Spanish nuclear power plants.

The collected data show the few cases where actual, reliable, and well-defined figures are provided. According to the Supplementary material in Sesma-Martín \& Rubio-Varas (2017), in some of the data sources the numbers provided cover either water withdrawals or water consumption, but not both. On other occasions, the sources omitted specifying whether the figure provided referred to withdrawals or consumptions. Moreover, in recent years, electric utilities have produced environmental reports, that among others, provide data on their water consumption. However, these figures are useless for the purpose of estimating the water requirements of a given power plant as these reports only provide the total aggregated data on water usage without differentiating between cooling technologies or individual facilities. As explicit data for each nuclear power plant are lacking for most Spanish reactors, Sesma-Martín \& Rubio-Varas (2017) resorted to estimations based on the international literature. All Spanish reactors are of American manufacture, except for two of them (De la Torre \& Rubio-Varas, 2016). Therefore, by reviewing the American literature on cooling technology and water factors, Sesma-Martín \& Rubio-Varas (2017) applied those standard factors for the equivalent reactors and produced their estimated time series of the water footprint for nuclear plants in Spain. However, they did not compare and contrast the different estimates they collected, nor compare them with their own estimations based on water factors from the international literature. We conducted such comparisons to expose the insufficient precision and inconsistent data available on the water-energy nexus in Spain.

\section{Results}

Figures 3 and 4 show the comparison between the different water withdrawals and consumption factors for each of the Spanish nuclear reactors from the available published sources on water needs provided in Sesma-Martín \& Rubio-Varas (2017). In turn, these figures are associated with Tables 1 and 2, which show some statistics for evaluating the absolute and the relative quality of the data. 


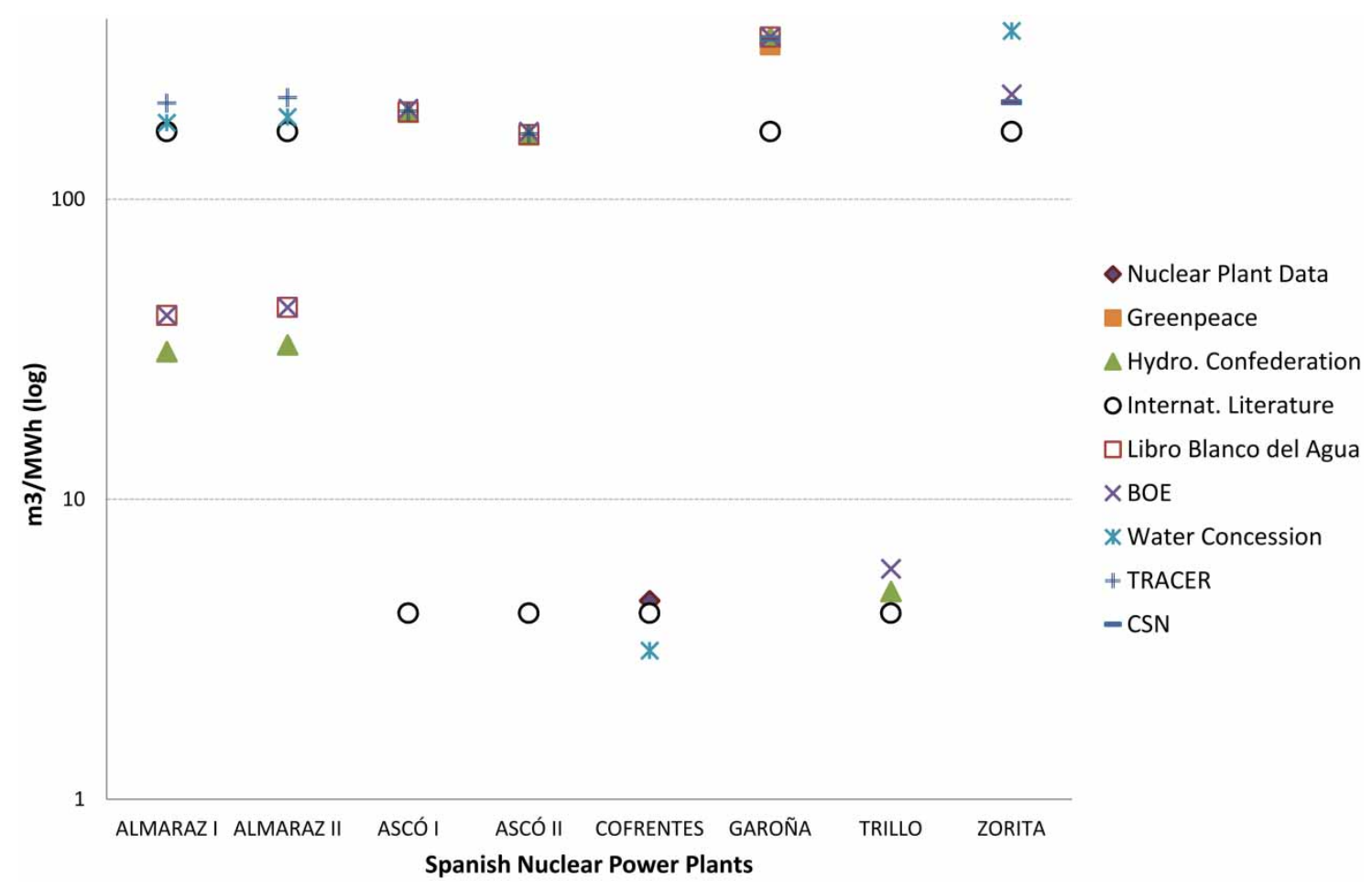

Fig. 3. Sample data of the water withdrawal factors for Spanish nuclear power plants. Note: $\mathrm{m}^{3}=$ cubic meter. Source: Elaborated from individual reactor published data available from the Supplementary material in Sesma-Martín \& Rubio-Varas (2017).

As we can see, the differences are of several orders of magnitude, especially when comparing the water withdrawal coefficients deducted from the different sources for each nuclear power plant in Figure 3. More specifically, while data exist for the technical factor on water withdrawals for all nuclear power plants, there have been no data published for three of the eight nuclear plants in the case of water consumption, except for the data estimated based on the literature review (Figure 4). In this way, when evaluating in absolute terms in the case of water withdrawals (Table 1), the nuclear power stations with the lowest range, in other words, lesser distance or dispersion among data, are Cofrentes and Trillo. In all other cases (i.e., Almaraz I-II, Ascó I-II, Garoña, and Zorita) the range is wider, as the data are further apart from each other. Likewise, for evaluating the relative quality of data we have calculated the coefficient of variation $(\mathrm{CV})$ which shows the dispersion of data in relation to the average. Now the power plants with the lowest values are Trillo (0.17), Cofrentes (0.19), Garoña (0.23), and even Zorita (0.35). However, Almaraz I-II and Ascó I-II have a greater coefficient $(0.74,0.73$, and 0.54 , respectively). Conversely, the picture for water consumption is very different. No official data exist for the Garoña and Ascó nuclear power plants and the data for the rest of the cases present differences of various orders of magnitude. Thus, whereas Cofrentes, Trillo, and Almaraz I-II capture the lowest ranges $(0.10$, $0.19,2.30$, and 2.44 respectively), Zorita's range (14.08) stands out extremely among the rest. Finally, when assessing the relative differences, we find in Cofrentes and Trillo the lowest 


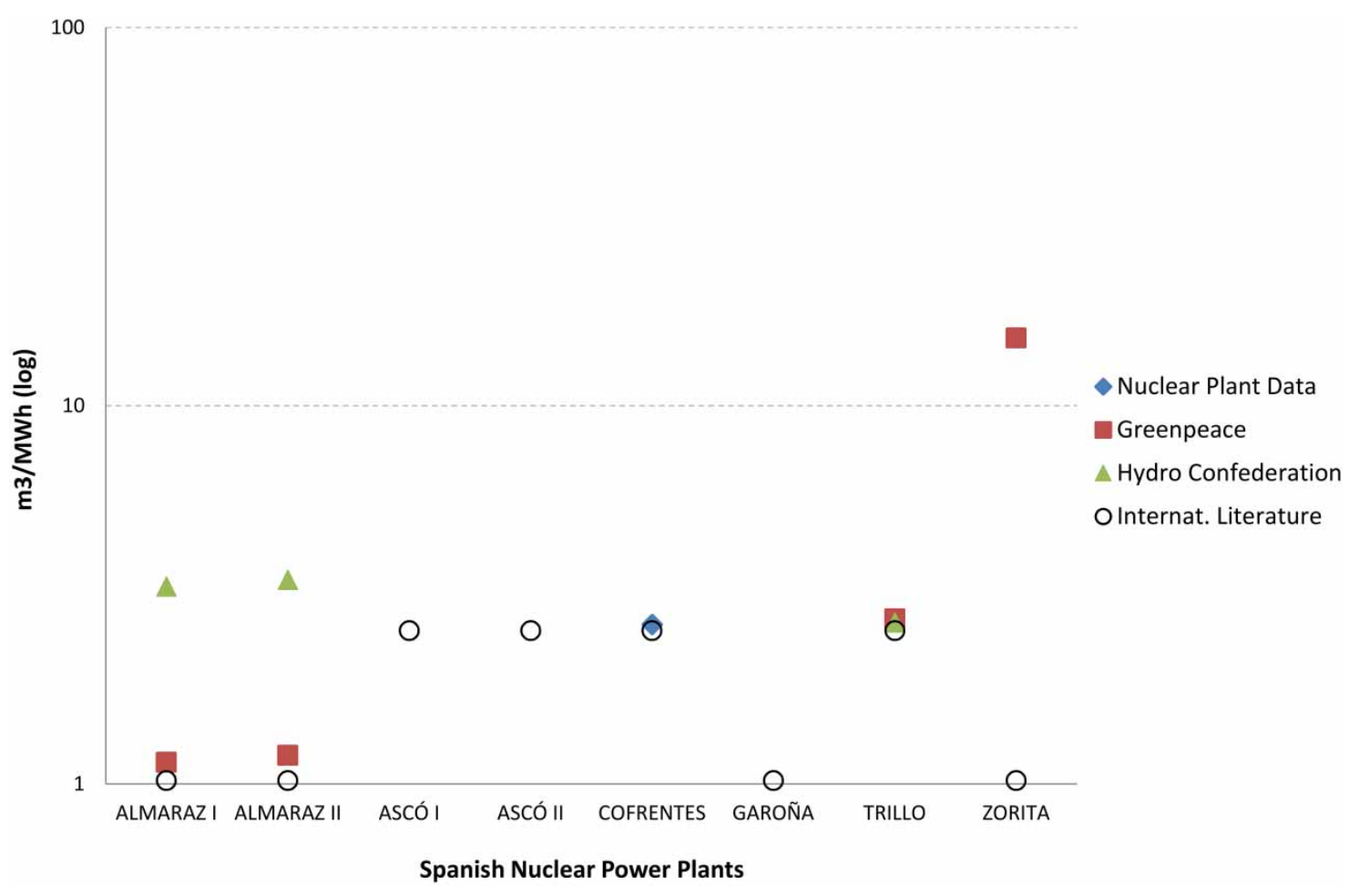

Fig. 4. Sample data of the water consumption factors for Spanish nuclear power plants. Note: $\mathrm{m}^{3}=$ cubic meter. Source: Elaborated from individual reactor published data available from the Supplementary material in Sesma-Martín \& RubioVaras (2017).

Table 1. Statistics for data on water withdrawals' factors $\left(\mathrm{m}^{3} / \mathrm{MWh}\right)$.

\begin{tabular}{lllllllll}
\hline & ALMARAZ I & ALMARAZ II & ASCÓ I & ASCÓ II & COFRENTES & GAROÑA & TRILLO & ZORITA \\
\hline $\mathrm{N}$ & 6 & 6 & 5 & 5 & 3 & 6 & 6 & 3 \\
$\mathrm{Max}$ & 209.00 & 218.00 & 200.60 & 168.00 & 4.59 & 347.70 & 5.86 & 364.15 \\
$\mathrm{Min}$ & 31.00 & 32.68 & 4.17 & 4.17 & 3.13 & 167.88 & 4.17 & 167.88 \\
Range & 178.00 & 185.32 & 196.43 & 163.83 & 1.46 & 179.82 & 1.69 & 196.27 \\
Median & 111.65 & 115.63 & 158.31 & 133.03 & 3.96 & 313.18 & 4.98 & 241.73 \\
$\mathrm{SD}$ & 82.22 & 84.50 & 86.20 & 72.06 & 0.75 & 71.64 & 0.85 & 85.06 \\
$\mathrm{CV}$ & 0.74 & 0.73 & 0.54 & 0.54 & 0.19 & 0.23 & 0.17 & 0.35 \\
\hline
\end{tabular}

Note: $N=$ data frequency; $\mathrm{Max}=$ maximum value; $\mathrm{Min}=$ minimum value; Median $=$ arithmetic average $\mathrm{SD}=$ standard deviation; $\mathrm{CV}=$ coefficient of variation.

Source: Elaborated from individual reactor published data available from the Supplementary material in Sesma-Martín \& Rubio-Varas (2017).

coefficients of variation, units I and II of Almaraz nuclear power plant involve an intermediate value $(0.71$ and 0.72$)$ and Zorita presents again the highest value, although far less remarkable than before (1.24). 
Table 2. Statistics for data on water consumption factors $\left(\mathrm{m}^{3} / \mathrm{MWh}\right)$.

\begin{tabular}{|c|c|c|c|c|c|c|c|c|}
\hline & ALMARAZ I & ALMARAZ II & ASCÓ I & ASCÓ II & COFRENTES & GAROÑA & TRILLO & ZORITA \\
\hline $\mathrm{N}$ & 3 & 3 & 1 & 1 & 2 & 1 & 3 & 2 \\
\hline Max & 3.32 & 3.46 & 2.54 & 2.54 & 2.64 & 1.02 & 2.73 & 15.10 \\
\hline Min & 1.02 & 1.02 & 2.54 & 2.54 & 2.54 & 1.02 & 2.54 & 1.02 \\
\hline Range & 2.30 & 2.44 & 0 & 0 & 0.10 & 0 & 0.19 & 14.08 \\
\hline Median & 1.83 & 1.89 & 2.54 & 2.54 & 2.59 & 1.02 & 2.65 & 8.06 \\
\hline SD & 1.29 & 1.36 & - & - & 0.07 & - & 0.10 & 9.96 \\
\hline $\mathrm{CV}$ & 0.71 & 0.72 & - & - & 0.03 & - & 0.04 & 1.24 \\
\hline
\end{tabular}

Note $: \mathrm{N}=$ data frequency; $\mathrm{Max}=$ maximum value; $\mathrm{Min}=$ minimum value; Median = arithmetic average $\mathrm{SD}=\mathrm{standard}$ deviation; $\mathrm{CV}=$ coefficient of variation.

Source: Elaborated from individual reactor published data available from the Supplementary material in Sesma-Martín \& Rubio-Varas (2017).

\section{Discussion}

In the case of the Spanish water-energy nexus, we have identified a number of sources (suppliers of information) that provide inconsistent and, at times, contradictory factual information for the amount of water required to operate the thermoelectric power plants (data), without specifying the particular procedures utilized to calculate such figures (no methodology). Furthermore, the data identified refer to benchmark estimates. There exists no statistical evidence on the evolution of the water requirements (neither withdrawals nor consumption) over time for any of the Spanish thermoelectric plants. Moreover, as mentioned above, "while data exist for the technical factor for water withdrawals for all nuclear power plants, there have been no data published for three of the eight nuclear plants in the case of water consumption'. Thus, our claim that the data on the water-energy nexus in Spain is weak.

Effectively, the problem lies mainly in the impossibility to identify from the sources that we collected, what concepts are being measured and estimated (water withdrawals, water consumption, or both). In other words, it is impossible to identify the methodologies utilized, which, in turn, contributes to make the little available data even feebler. The figures above show the evident lack of consensus among the different sources of information that collect water data regarding the estimation of freshwater resources needed for thermoelectric production. Management thinker Peter Drucker is often quoted as stating that 'you can't manage what you can't measure' and physicist Lord Kelvin, in a similar vein, has been attributed with the phrase 'if you cannot measure it, you cannot improve it'. With a clearly established metric for success, it is possible to quantify progress and adjust processes to produce the desired outcome. Without a clear indication of the size of a problem there is no reason to worry or act to solve it. For example, in the USA, water withdrawal and consumption data have been available for almost all thermoelectric power generating units and cooling systems in the country for many years and, hence, the water-energy nexus is a matter of greater relevance for American policy-makers. Thus, we contend that the fact that the water-energy nexus has not been considered a critical issue in the Spanish policy agenda has largely to do with the lack of consistent indicators about it. Moreover, lack of studies on the estimation of the water requirements for thermal power generation so far in Spain could be related to the limited official statistics on the water-energy nexus, which makes this type of analysis impossible. In this respect, in 2013, Spain signed an agreement for the construction of a more transparent and open government through the approval of the Transparency Law (Law 19/2013, December 9, of 
Transparency, Access to Public Information and Good Governance). Likewise, this country also signed the creation of a specific portal on open data. However, there has been little compliance with these agreements. According to the Index of Water Management elaborated by the non-governmental organization International Transparency ${ }^{5}$, in Spain there are still significant gaps in publicly available information in some areas of public management. Furthermore, when ranking by data typology, all those data related to uses of water are the most limited, appearing in the last position of the ranking. De Stefano et al. (2018) in a recent study about open data in the Spanish water sector also confirm these statements.

We plead that Spanish energy leaders and those responsible for the energy policy of the country consider water as the critical energy resource that it is. In this sense, working in producing accurate data on the evolution of the water withdrawals and consumption seems to be a key issue to move towards a better estimation of the thermoelectric water footprint. Better data will also help to improve the awareness of the different tradeoffs between water uses (i.e., withdrawals and consumptions) according to different cooling technologies and alternative ways of producing electricity. This is particularly important, not only when taking water policy measures and planning future energy systems, but also when analyzing special cases such as Spain, with increasingly frequent episodes of drought. Moreover, the publication of data related to uses of water within the energy sector in official and open sources of information would also contribute to the generation of new knowledge and studies on this matter. Ultimately, a better understanding of this problem in Spain could provide short- and long-term strategies to cope with vulnerability and resilience in power plants in future water stress scenarios.

After the analysis of sources of information carried out in this paper, we conclude that the environmental reports produced by thermal power plants are the best sources to estimate the annual water footprint. However, this improvement in data production and collection would be of little value if the environmental reports remain inaccessible (although for some plants they are already public, in most cases they are not). There exists no systematic effort to make them public. Thus, the Spanish Ministry of Agriculture, Fisheries, Food and Environment (MAPAMA, as known by the Spanish acronym) or the Hydrographic Confederations, as public regulatory bodies of the Spanish river basins and dependent on the Spanish Ministry of Environment, could represent the most relevant authorities to collect and publish on their websites these kinds of data. Additionally, we believe that some of this information should also be included in the Libro Blanco del Agua, the most representative reference on water problems in Spain, where only eight of the 637 pages of the full text are dedicated to the water-energy nexus.

Finally, making strict use of the definition of 'Economy' as the discipline that studies the distribution of scarce resources among competing needs, our interest as economists is to assess the amounts of fresh water required for thermoelectric production. Therefore, in this paper, we only focus on the quantitative importance of water, leaving aside the qualitative aspects (i.e., temperature, liquid effluents, or radioactive solid wastes) which require a different approach. This could be a potential issue to be addressed in future analyses, especially in the Iberian Peninsula, where three main rivers cross the border flowing from Spain into Portugal and four nuclear reactors have used water from the Tagus River for cooling from the middle of the 20th century onwards (Rubio-Varas et al., 2018).

In summary, we hope this information will encourage better data collection on the water-energy nexus in Spain, as well as a more transparent and consistent publication of the data in open platforms

\footnotetext{
${ }^{5}$ More information about International Transparency-Spain can be found at https://transparencia.org.es/.
} 
in order to improve future studies that are crucial for policy-makers. Will water limit our energy future? How should water be taken into account when planning the electricity mix of the future? Questions like these will become crucial in the coming years.

\section{Acknowledgments}

This work was supported by the Spanish Government through the MINECO research projects reference HAR2014-53825-R and HAR2017-86086-R. The first author also benefits from a research contract with the Spanish Government through the MINECO reference BES-2015-074128. We appreciate the helpful comments and suggestions received by the three anonymous reviewers. Both authors have contributed equally to the development of this document. The authors declare no conflict of interest. The founding sponsors had no role in the design of the study; in the collection, analyses, or interpretation of data; in the writing of the report, and in the decision to submit the article for publication.

\section{References}

Carrillo, A. M. R. \& Frei, C. (2009). Water: a key resource in energy production. Energy Policy 37(11), 4303-4312.

Cazcarro, I., Hoekstra, A. Y. \& Chóliz, J. S. (2014). The water footprint of tourism in Spain. Tourism Management 40, 90-101. DOI: http://dx.doi.org/10.1016/j.tourman.2013.05.010.

De la Torre, J. \& Rubio-Varas, M. (2016). Nuclear power for a dictatorship: state and business involvement in the Spanish atomic program, 1950-85. Journal of Contemporary History 51(2), 385-411. DOI: https://doi.org/10.1177/0022009415599448.

Delgado, A., Rodriguez, D. J. \& Sohns, A. A. (2015). Thirsty Energy: Understanding the Linkages Between Energy and Water. Live wire knowledge notes series; no. 2015/41. World Bank Group, Washington, DC, USA. http://documents.worldbank. org/curated/en/2015/01/24084417/thirstyenergyunderstanding-linkages-between-energy-water (accessed 4 January 2018).

De Stefano, L. \& Llamas, M. R. (2012). Water, Agriculture and the Environment in Spain: Can We Square the Circle? CRC Press, Boca Raton, FL, USA.

De Stefano, L., Cabello, V. \& Hernández-Mora, N. (2018). Datos Abiertos en el Sector del Agua en España (Open Data in the Water Sector in Spain) Fundación Botín.

Duarte, R., Pinilla, V. \& Serrano, A. (2014). The water footprint of the Spanish agricultural sector: 1860-2010. Ecological Economics 108, 200-207. DOI: https://doi.org/10.1016/j.ecolecon.2014.10.020.

Garrues-Irurzun, J. \& López-García, S. (2009). Red Eléctrica de España SA: instrument of regulation and liberalization of the Spanish electricity market (1944-2004). Renewable and Sustainable Energy Reviews 13(8), 2061-2069.

Hardy, L., Garrido, A. \& Juana, L. (2012). Evaluation of Spain's water-energy nexus. International Journal of Water Resources Development 28(1), 151-170.

IEA (International Energy Agency) (2012a). World Energy Outlook 2012. Paris, France. https://www.iea.org/newsroom/news/ 2012/november/world-energy-outlook-2012.html (accessed 24 February 2018).

IEA (International Energy Agency) (2012b). Water for Energy: is Energy Becoming A Thirstier Resource? Paris, France. http:// www.worldenergyoutlook.org/media/weowebsite/2012/WEO_2012_Water_Excerpt.pdf (accessed 4 January 2018).

IEA (International Energy Agency) (2013). World Energy Outlook 2013. Paris, France. https://www.iea.org/publications/freepublications/publication/WEO2013.pdf (accessed 24 February 2018).

Kenny, J. F., Barber, N. L., Hutson, S. S., Linsey, K. S., Lovelace, J. K. \& Maupin, M. A. (2009). Estimated use of Water in the United States in 2005. U.S. Geological Survey Circular 1344, p. 52. https://pubs.usgs.gov/circ/1344/ (accessed 4 January 2018).

Macknick, J., Newmark, R., Heath, G. \& Hallett, K. C. (2012). Operational water consumption and withdrawal factors for electricity generating technologies: a review of existing literature. Environmental Research Letters 7(4), 045802. DOI: https://doi. org/10.1088/1748-9326/7/4/045802. 
Meldrum, J., Nettles-Anderson, S., Heath, G. \& Macknick, J. (2013). Life cycle water use for electricity generation: a review and harmonization of literature estimates. Environmental Research Letters 8(1), 015031. DOI: https://doi.org/10.1088/17489326/8/1/015031.

REE (Red Eléctrica de España) (2017). The Spanish Electricity System. Preliminary report 2017. Madrid. http://www.ree.es/ sites/default/files/downloadable/avance_informe_sistema_electrico_2017_eng.pdf (accessed 24 February 2018).

Rodriguez, D., Delgado, A., DeLaquil, P. \& Sohns, A. (2013). Thirsty Energy. Water Papers. World Bank, Washington, DC, USA. http://documents.worldbank.org/curated/en/835051468168842442/Thirsty-energy (accessed 4 January 2018).

Rubio-Varas, M. d. M., Carvalho, A. \& De la Torre, J. (2018). Siting (and mining) at the border: Spain-Portugal nuclear transboundary issues. Journal of History, Environment and Society 3, 33-69.

Sesma-Martín, D. (2017). Water for Power Generation: Vulnerability, Conflicts, and Competition in the Ebro River Basin. In: Conference Proceedings of the XLIII Reunión de Estudios Regionales - International Conference on Regional Science, Sevilla. Spanish and Andalusian Regional Science Associations (eds). http://old.reunionesdeestudiosregionales.org/ sevilla2017/es/xliii-reunion-de-estudios-regionales/papers.html (accessed 24 February 2018).

Sesma-Martín, D. \& Rubio-Varas, M. (2017). Freshwater for cooling needs: a long-run approach to the nuclear water footprint in Spain. Ecological Economics 140, 146-156. DOI: https://doi.org/10.1016/j.ecolecon.2017.04.032.

UN Water (23 November 2016). Para qué sirven los Días Internacionales? (What are International Days for?) https://blogs.un. org/es/2016/11/23/para-que-sirven-los-dias-internacionales/ (accessed 29 March 2018).

WEC (World Energy Council) (2014). World Energy Council Issues Monitor 2014. What keeps Energy leaders awake at night?, London. https://www.worldenergy.org/wp-content/uploads/2014/01/World-Energy-Issues-Monitor-2014.pdf (accessed 4 January 2018).

WEC (World Energy Council) (2015). World Energy Council Issues Monitor 2015. Energy price volatility: the new normal, London. https://www.worldenergy.org/wp-content/uploads/2015/01/2015-World-Energy-Issues-Monitor.pdf (accessed 4 January 2018).

WEC (World Energy Council) (2016). World Energy Council Issues Monitor 2016. A climate of innovation-responding to the commodity price storm, London. https://www.worldenergy.org/wp-content/uploads/2016/03/2016-World-Energy-IssuesMonitor-Full-report.pdf (accessed 4 January 2018).

WEC (World Energy Council) (2017). World Energy Council Issues Monitor 2017. Exposing the New Energy Realities, London. https://www.worldenergy.org/wp-content/uploads/2017/04/1.-World-Energy-Issues-Monitor-2017-Full-Report.pdf (accessed 4 January 2018).

World Nuclear Association (2018). Nuclear Power in France. http://www.world-nuclear.org/information-library/countryprofiles/countries-a-f/france.aspx (accessed 29 March 2018).

WWAP (World Water Assessment Programme) (2014). The United Nations World Water Development Report 2014: Water and Energy. UNESCO, Paris. http://www.unesco.org/new/en/natural-sciences/environment/water/wwap/wwdr/2014-waterand-energy/ (accessed 4 January 2018)

Received 26 April 2018; accepted in revised form 15 December 2018. Available online 21 January 2019 